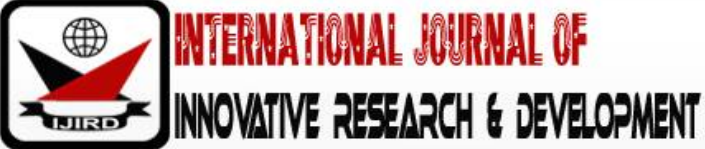

ISSN 2278 - 0211 (Online)

\section{Shaping, Beautifying and Environmental Management of Our Cities Through the Use of Plants: A Jos City Centre, Scenario, Nigeria}

Emmamoge Orewere
Lecturer, Department of Horticulture and Landscape Technology,
Federal College of Forestry, Jos, Nigeria
Ann Muopwun Katyen
Lecturer, Department of Architecture, University of Jos, Nigeria
Musa Amos Tarni
Lecturer, Department of Architecture, University of Jos, Nigeria
Comfort Nnenna Okoronkwo
Instructor, Department of Horticulture,
Nigeria Cross River Institute of Technology and Management, Cross River State, Nigeria

\begin{abstract}
:
Many of our cities and towns lack adequate trees to modify and beautify the environments. Nigerian cities of today face numerous problems these include urbanization, deteriorating environment, urban decay, un-cleared refuse, flooding, erosion and pollution. Little or no attention has been given to management of the environment and appropriate landscaping of our houses, neighborhood, towns and cities in recent times. About $85 \%$ of the surroundings of the city center are covered with hard landscape elements such as asphalt, interlocks, concrete resulting into heat islands around the exterior of buildings. Thus, the indoor temperature is usually high due to heat transfer from paved surfaces. This study aims to examine how plants are used in shaping, beautifying and the environmental management of Nigerian urban centres. The study area is Jos the capital of Plateau State situated in the North-Central geopolitical zone of Nigeria. Qualitative method was adopted for this paper, which involves the study and review of existing literature on the subject, reconnaissance survey and case studies. The findings reveal that the level of landscape development within the city centre is grossly inadequate. This study posits the use of plants as landscape elements beautifies our cities, improve air quality, as well as creating pleasant scenes of our major roads, roundabout, recreation centers which invariably gives a healthy environment devoid of environmental hazards. The paper recommends that appropriate sensitization programmes on values of landscaping should be intensified to individuals, professionals, Government and Non-governmental organizations.
\end{abstract}

Kevwords: Beautifyinq, city centre, environmental manaqement, ios, plants, shapinq

\section{Introduction}

The first visible developmental assessment of any place or people is through the physical structures and the general environmental portrait. Other indices of measurement come second. (Agbonome, et al., 2014). The environment is an interactive, indispensable medium, within and through which man's life performance is carried out. Man's life in his present nature is unimaginable without the environment to supply him with his needs such as air (to breathe), water (to drink and wash with), food (to eat), and solid materials for fashioning weapons, building shelters and clothing (Atolagbe 2002), as cited by Fadamiro, et al., (2006).It is a known fact that human activities such as industrialization, urbanization, mining, infrastructure development and agriculture have been exerting pressure on the land mostly in urban centres. Consequently, the environment has been deteriorating over large parts of the country (Adams,et al., 2002).

About $85 \%$ of the surroundings of the city center are covered with hard landscape elements such as asphalt, interlocks, concrete resulting into heat islands around the exterior of buildings. Thus, the indoor temperature is usually high due to heat transfer from paved surfaces. Researcher's such as (Ogunsote \& Prucnal-Ogunsote, 2004; Agboola, 2011; Ayeni, 2012, 2013; Dipeolu, et al., 2015; Ale, et al.,2019) have equally called for the greening of urban areas as a means to ameliorate the climate, lower solar radiation, reduce temperature, winds and possibly improve the rainfall pattern. The use of space is limited having cleared the vegetation for the purpose of constructing roads and erecting buildings in the urban areas, the vegetation that has the capacity for protective, aesthetic and/ or medicinal purposes among others should be re-established (Adams, et al., 2002). 
Landscaping is a neighbourhood amenity which may be used to improve and sustain the quality of life whether in the city, suburbs or the country (Bello, 2016). Ayeni, (2012) described it as the art of modifying and creating beautiful environments using various elements such as living elements and man-made elements. Generally, landscaping is perceived as the art of caring for the environment. Hence the cliché - landscapes of care (Ibimilua, 2014).

Hence, landscape design elements can be classified into two such as the soft landscape and hard landscape. The soft landscape describe the vegetative materials which are used to improve a landscape by design. The corresponding term hard landscapeis used to describe construction materials. The range of soft landscape materialsincludes each layer of the ecological sequence: aquatic plants, semi-aquatic plants, field layer plants: trees, groundcover, hedges, shrubs and flowers (Siyanbola, 2011; Ayeni, 2012).The functionality, the beauty and compatibility with the natural environment are the result of the combined efforts of the landscape designer, the landscape architect and the architect to give an aesthetically pleasing environment (Ayeni, 2012).However, in Nigeria, the practice, quality and patronage of city landscaping and such services is still at the early stages when compared to what obtains in more technologically advanced and developed countries. It is of great interest that colonialism helped change and introduce the practice of formal landscaping of some public buildings as well as Government Reservation Areas (GRAs), (Olubode, 2016). More recently, there has been an increase in the practice of city landscaping in cities such as Abuja, Calabar, Uyo and Lagos among others.

This paper, therefore, documents how plants play a vital role in shaping, beautifying and enhacing environmental management. This will be achieved by, examining the existing landscape pattern within the city centre and also providing an appropriate planting scheme towards creating a functional and balance use of plant materials.

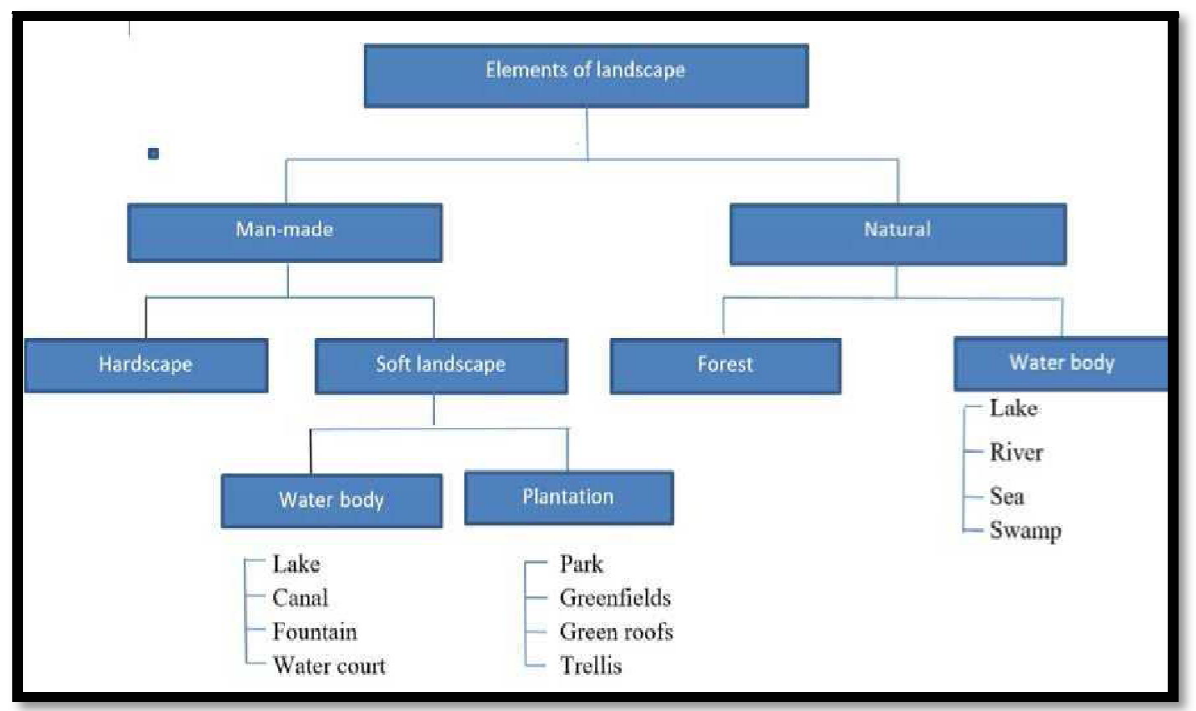

Figure 1: Elements of Landscape

Source: Adapted from Ale, Et Al., 2019

Figure 1 above shows the classification of landscape elements grouped into manmade and includes hardscape, soft cape, water bodies and plantation and natural that is the forest, rocks, ground form and water body (Ale,et al., 2019).

\section{Literature Review}

\subsection{Concept of Soft Landscape}

Nikolaenke as cited by Omokhua, et al., 2002, asserts that plants are the lungs of the earth.Soft landscape: refers to the living or natural materials used in landscaping (Ayeni, 2012; Adekunle, et al., 2016 ;) these include trees, groundcover, hedges, shrubs and flowers. They are collectively known as vegetation (Ayeni, 2012).Generally, soft landscape serves the functions of screening and maintaining privacy, which breaks the monotony of view; provides habitat for animals-which is important for biodiversity, visual enhancement, erosion control, noise pollution, demarcations, shading, wind breakers as well as air purification (Ayeni, 2012).

- Trees:Trees are the most significant in the provision of shade and the control of relative humidity and air movement. They contribute more to the attainment of thermal comfort than any other element. Ventilation is affected by plant materials. Air crossing hard reflective or absorptive surfaces like parking lots and sidewalks is warmed, but air passing through trees and plants will be cooled (Siyanbola, 2011).While Trees in landscaping are used not only for aesthetic purposes but also create shades, are arranged in rows to create vistas, used as focal points and can be placed in a straight line for effect (Ayeni, 2012).

- Shrubs: Shrubs come in a variety of appearances, some flowering and others evergreen. They can be used as barriers, ground cover and to direct pedestrian traffic flow as well as serve as a barrier for unwanted foot traffic (Ayeni, 2012).

- Flower:Flowers and flower beds give colour and attractive effects to the landscape. They can be grouped together, arranged symmetrically or in asymmetrical patterns and in different shapes to give a beautiful design (Ayeni, 
2012).Flowerbeds are used to reduce ground temperature and to prevent glare. Vegetation generally improves air freshness and fragrance (Siyanbola, 2011).

- Lawns: Lawns are made from grass and other ground covers used in private gardens, public gardens and parks and used to create aesthetics (Ayeni, 2012).They also reduce ground temperature and prevent glare.

- Hedges: Hedges can be used to mark property lines, screening views, provide barriers and also as wind breakers. They can be from trees or shrubs, planted close together in a row. Could be formal or informal, trimmed and pruned to add beauty to the landscape and can also be used in fences (Ayeni, 2012).

- Mulches: Mulch is a protective covering over the roots of trees and bushes to retain moisture and kill weeds. Mulches include straw, fallen leaves or plastic sheeting. Others are gravel, wood chipping, rotting leaves and grass. Mulches can be used to reduce surface and air temperatures by reducing the heat absorbed by the ground (Siyanbola, 2011).

- Trellis and Climbers: A trellis is a light framework of crossing strips of wood, plastic, et cetera used to support climbing plants and it is often fastened to a wall. This can be used to provide shade on western walls (Siyanbola, 2011).

- Pools and Ponds: These water bodies are used for humidification and evaporative cooling (Siyanbola, 2011).

\subsection{Role of Vegetation in City Landscaping}

City landscaping can be described as the act of making changes or modifying the present physical terrain on which a city is located, by addition of plants and the construction of man-made structures in order to enhance its aesthetic and natural values as well as create useable space for outdoor activities. It is without a doubt that the gradual process of urbanisation, over the years, has altered natural landscapes and this has caused negative impacts on the physical environment Calderon, (2009).He opined that urban or city landscaping is centred around public spaces in a city "such as parks, squares, streets, boulevards, natural parks, surplus areas, left over areas, abandoned industrial or urban sites, etc.", though with a special bias for open spaces. "The landscape is planned, designed or shaped to convey human intention and it is affected by the social, physical and natural context in which it is embedded."

Plant materials are described as soft landscape materials (Ale,et al., 2019). Plants play a vital role in a community's scenic beauty, the character of the local landscape and the overall quality of the environment. Despite their benefits, plants are disappearing faster than we think. Just imagine what our streets and neighbourhoods would be like without plants! Benefits of establishing and protecting plants include:

\subsubsection{Aesthetic Value}

Our cities lack adequate trees to modify and beautify the environment. Plants provide a variety of aesthetic values and accentuate the architectural design of buildings. Avenue plants such as Thuja plicata, Lagaestromia indica, Caryota mitis,Juniperus chinensis, Hura crepitans, Casuarina equisetifolia, Acacia spp.on our roads and pedestrian walkways create a safer restful and scenic view and provide shade to the pedestrians and other road users. Trees in a single or double row have strong visual impact. This arrangement is suitable for the urban or built environment (Adams, et al., 2002; Okoronkwo, 2017).

\subsubsection{Environmental Value}

\subsubsection{Reducing Gaseous Air Pollutants}

Trees can be effective in reducing gaseous air pollutants such as dust, sand, fly ash, pollen and smoke. Mbakwe's study as cited in Adams, et al., (2002) says an investigation in Germany revealed that a tree produces $1.7 \mathrm{~kg}$ of oxygen per hour. The current increase in automobiles in the urban cities underscores the need of plants to check gaseous discharge in the atmosphere. Some plants such as Brunfelsia hopeana, Neriun oleander, Eucalyptus saligna etc. Produce sweet scent capable of neutralizing the polluted air thereby making the air fresh for human consumption (Adams, et al., 2002).

\subsubsection{Air Purification}

Particles of air pollutants are absorbed by leaf surfaces or they may be deposited on the leaves as they fall on the soil, they are absorbed. Kecher's study as cited by Mbah, (2001) indicated that quantified pollution remediation by plants and showed that $85 \%$ of lead from vehicles can be removed by a shelter belt of trees. Landscaping plants mask fumes and disagreeable odour by replacing them with more pleasing scents or absorbing them. Air flow modification caused by these plants affect transport and diffusion of water pollutants and energy. Trees particularly and other plants through their growth processes act as a sink for atmospheric carbon dioxide, the predominant greenhouse gas.

Mbah, (2001), assert increased trees in the landscape will potentially slow the accumulation of atmospheric CO2.In addition, the production of $\mathrm{CO} 2$ by fossil powered generating plants will be reduced and energy conserved. Some plants such as Eucalyptus saligna, Brunfelsia hopeana, Nerium oleanderetc. produce sweet scent capable of neutralizing the polluted air thereby making the air fresh for human consumption.

\subsubsection{Erosion Control}

Trees and shrubs could serve as shield to cover the bare soil while holding the soil together and their roots serving as barriers against run-offs. The characteristic features of plants in land reclamation and erosion control is that their strong spreading roots help to hold the soil particles together (Adams, et al., 2002). Most of the incidences of soil 
erosion in urban centres can be minimized if appropriate and well planned tree planting is combined with other developmental activities.

Trees such as Terminalia catappa has strong spreading roots that can hold the soil together. Planting of drought resistant trees such as Azadirachta indica and Acacia spp in the Northern part of the country could be effectively used to checkmate the deleterious effects of wind storm common in Kano, Borno and Sokoto States. Ogigirigi's study as cited in Adams, et al., (2002), found that the wind breaking effect of trees has caused the reduction of wind speed by as much as $30 \%-50 \%$.Trees and shrubs should be systematically arranged in the direction of the prevailing wind in order to form strong obstruction and resistance against the speed of turbulent windstorm and consequently check its devastating effects.

\subsubsection{Reduced Noise Pollution:}

Noise pollution is an often overlooked problem. Excessive or unwanted sound has negative physical and psychological effects. Noise can come from many sources, especially roads and highways. Trees can play an important role in deadening unwanted noise. Sound waves are absorbed by a tree's leaves, branches, and twigs. Studies suggest that belts of trees 100' wide and 45' long can cut highway noise to half (A Handbook of Landscape, 2013).

\subsubsection{Humidity Control}

Humidity is a measure of the amount of water vapor in the air (Ahrens, 2007). As long as heat present, the heat energy will be absorbed by moisture and released to the air in exchange for the use of heat energy. Plants in general increase the humidity of the site. They can therefore increase the thermal comfort during hot, dry seasons, although the plants have to be watered regularly. The plants take water from the soil, and when this water evaporates from the leaves it increases the relative humidity while lowering the air temperature. Pools and ponds behave in a similar manner. Water evaporating from the surface increases relative humidity while reducing air temperature (Adedeji, et al., 2010).

\subsubsection{Lower Heating and Cooling Costs}

Plants have demonstrated the ability to reduce heating and cooling costs and counteract the "heat island" effect in urban environments. Urban areas with little vegetation can experience temperatures of up to seven degrees higher than those with tree cover. This translates into significantly higher energy costs to cool buildings. Properly established plants can cut heating and cooling costs by as much as $12 \%$ and reduce overall power demand (A Handbook of Landscape, 2013).

\subsubsection{Modification of Temperature:}

Landscape planting especially trees and shrubs modify solar radiation, for example through provision of shade. The amount of radiant energy absorbed, stored or radiated by buildings and concrete surfacing in the living environment is significantly reduced by shading. Evapotranspiration in planted landscapes helps reduce sensible heat which warms air and the result is reduced temperature. It is estimated that tree planting around houses reduces energy for cooling by 10 to $50 \%$ and in temperate climate where heating may be needed, it is reduced by 4 to $22 \%$ (NNA/ ISSA, 1991;Mbah, 2001).

\subsubsection{Water Quality}

Plants help anchor soil and reduce storm water runoff, saving the high costs of drainage ditches, storm sewers, and other "engineered solutions" to storm water management. A Street lined with 32' tall trees can reduce runoff by almost 327 gallons, allowing cities to install smaller and less expensive water management systems. Reducing runoff also decreases topsoil erosion and the amount of silt and other pollutants washed into streams, rivers and lakes (A Handbook of Landscape, 2013).

\subsubsection{Health Value}

There is mounting evidence that stress and noise have an impact on our physical and psychological health. Trees and vegetation can affect our mood and help relieve stress. Plants include Araucaria spp,Grevillea robusta and Agava sisalana(A Handbook of Landscape, 2013).

\subsubsection{Shelter}

The shade of trees is welcomed by man and beast alike, providing essential shelter in the hottest climates. Trees are often used as windbreaks to shelter sensitive crops (A Handbook of Landscape, 2013).Example is Caesalpinia pulcherrima, Tectona grandis

\subsubsection{Fences/Boundary Demarcation}

Plant species such as Durantarupens, Dodonea viscosa,Hibiscus spp., The vetia peruviana,Rosa sinensi are used in constructing fences in our surroundings. While Popular woody species such as Lonchocarpus cyanescens,P.santalinoides, Millefia thonningii Jatropha species,Dracaena mannThevetia peruviana, Moringa oleifera,Calotropis procera serve for boundary demarcation in both urban and rural landscapes in Nigeria. They demarcate boundaries between church lands, school lands and farm lands (Omokhua, et al., 2002).Fences around private buildings provide, restrict movement of domestic animals and eliminate trespass.They are also used in primary, secondary and tertiary institutions in game courts. 


\section{Materials and Methods}

\subsection{Source of Data}

Data was drawn from primary and secondary sources. The secondary data involves the use of information already in existence and this was sourced largely through literature review. Primary data used was acquired through field survey and case study.

\subsection{Research Design}

This study used a combination of field survey, and case studyto obtain information concerning the currentstatus of problems and also to describe "what exists" with respect to the conditions in particular situations.The case study method was adopted so as to study Jos City Centre with a view to extract relevant data from it while the descriptive method uses the data so obtained to provide deep insight into roles of plants in landscaping.

\subsection{Background of Jos}

Jos is a town that its background and growth dates back to the early 19th century and also its commercial and cosmopol it an ascendency is as a result of the mining activities in Tin and Columbite in its general area (Oko, 2016).The town is also a terminal for railway line. At the outskirt, is an international airport, the Yakubu Gowon International Airport at Haipang. Through all these periods there have been steady and continuous increase in human population, businesses, buildings and other paraphernalia of urbanization including cars busses, trucks and articulated vehicle as major means of transportation within the city (Oko, 2016).

Jos is situated at about $\mathrm{N}^{\circ} 55^{\prime} 48^{\prime \prime}$ and E $8^{\circ} 53^{\prime} 24^{\prime \prime}$ in the Nigerian middle belt (Figure 2). The city is situated at the northern edge of a pear-shaped upland known as the Jos Plateau. This upland stretches for approximately $104 \mathrm{~km}$. from north to south, and $80 \mathrm{~km}$ from east to west covering an area of about $8,600 \mathrm{~km} 2$ or 860,000 hectares. It maintains an average height of $1200 \mathrm{~m}$ (4000ft) above sea level peaking at about $1766 \mathrm{~m}$ (5829ft) in the Shere Hills (Archives of National Centre for Remote Sensing Jos, 2007).

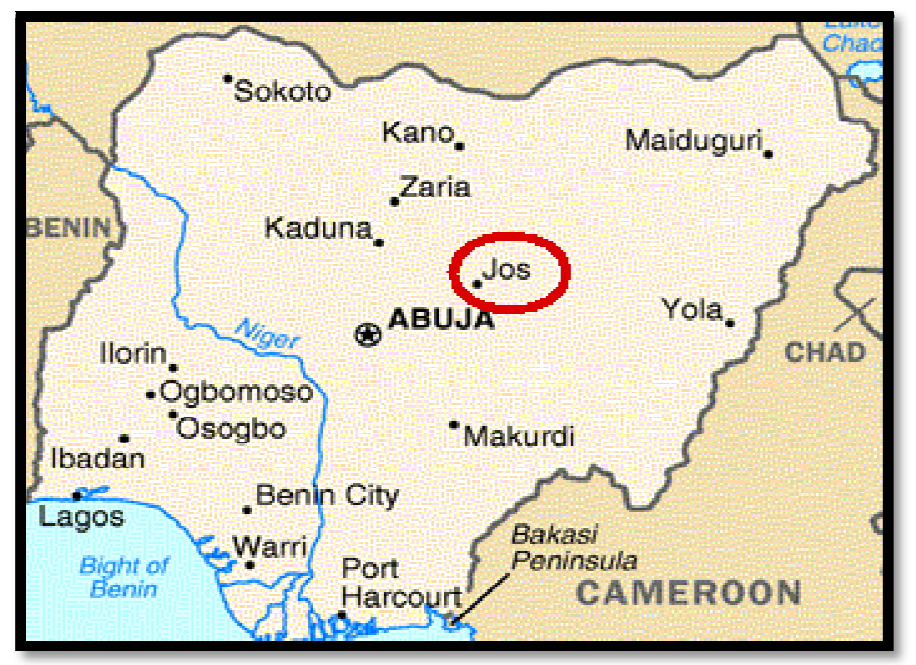

Figure 2: Map of Nigeria Showing Jos, Plateau

State Capital in Sphere

Source: Http:/ / Www.Plateaustategov.Org/ Visit/ Jos.Html

Jos city has an equable climate with average monthly temperatures ranging between $21^{\circ}$ and $25^{\circ} \mathrm{C}\left(69^{\circ}\right.$ and $\left.77^{\circ} \mathrm{F}\right)$, average humidity of $60 \%$ and average annual rainfall of 1,400 $\mathrm{mm}$ (56\&quot;).Jos falls within the tropical savannah region and as with most parts of the tropics, has two major seasons based primarily on the basis of rainfall and humidity levels. The two seasons are the rainy and dry season (harmattan season) characterized by the dominance of the moisture laden south west winds and the very dry and dusty north easterly winds with the associated easterlies respectively. (Archives of National Centre for Remote Sensing Jos, 2007).

\subsection{Study Area - Jos City Centre}

According to Oko, (2016), The CBD of the city is taken to be the general area, demarcated or circumscribed by the following roads and landmarks: Mango Street, Enugu road, up to the Polo Field, Joseph Gomwalk Road, Standard Building, Masallachi Juma Road, Tafawa Balewa Way, West of Mines Junction, Zoo Area, Central Bank/ Bank Street Area, Sharia Court of Appeal, Constitution Hill Road, Murtala Mohammed Way, Gangere Road, through Yam/ Potatoe Market, Dilimi Road, Nasarawa Road, turning left to cross Bauchi Road at Zololo Junction, and back to Mango Street(Oko, 2016). Thefollowing roads, areas and land marks, included in the CBD:

- The Masallachi Juma Street.

- Old Bukuru Park 
- Tafawa Balewa Way

- Rwang Pam Township Stadium

- West of Mines Junction

- Rwang Pam Street

- Langtang Street

- Shendam Street

- Panyam Street

- Church Street

- Ahmadu Bello way - beach road

- Murtala Mohammed Way

- Old Jos University Teaching Hospital

- The Jos Main Market and Precincts

- Bauchi road, from terminus rotary interchange to Zololo junction.

- Constitution hill road up to British America insurance junction

In this area there are 31 banks including the Central Bank, Jos, a total of 65 commercial buildings of overtwo storeys, over 30,000 stalls, stores, shops of small and big time traders and merchants, dealing on sundry items like building materials, clothes, books/ stationery, computers, accessories and repairs, restaurants, household items, mobile traders and hawkers (Oko, 2016).

Photographic survey of the city's major streets was used to gather qualitative data from different sites across the city. Observable areas of concern which were particularly considered included scenes of major streets, buildings and walls of Ahmadu Bello way - beach road, The Jos Main Market and Precincts,Murtala Mohammed Way and Rwang Pam Street (Researchers' Field Survey, 2019). Photos taken were labelled as "Plates" and each assigned a numeric identification.

\subsubsection{Micro Site Analysis of Jos City Centre}

\subsubsection{Site Area and Shape}

The Google Earth images, 2017 shows that the site is rectangular-shaped flanked by busy streets where commercial activities take place. Pedestrian lanes also make it accessible to pedestrians. Figure 3 and Figure 4 shows the cross section of the City Centre.

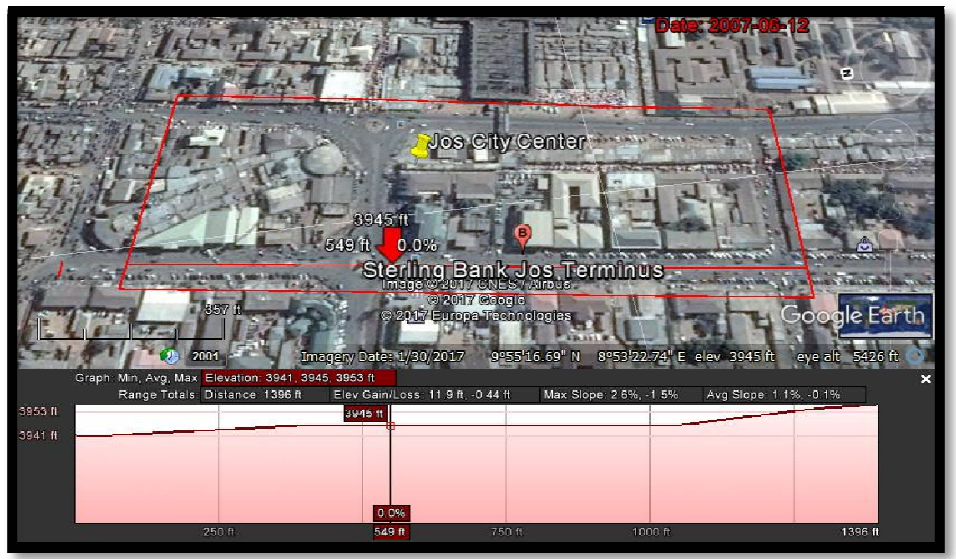

Figure 3: A Cross Section of Jos City Centre

Source: Google Earth Map, 2017

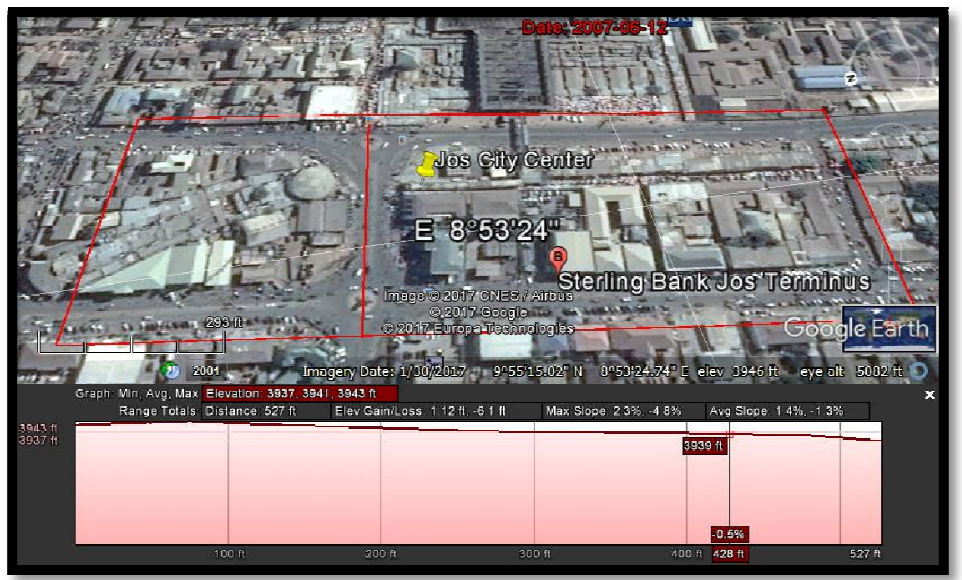

Figure 4: A Cross Section of the Jos City Centre

Source: Google Earth Map, 2017 


\subsubsection{Soil Type and Vegetation}

The soil type of the site is characterized with sandy clay distributed on unpaved pedestrian lanes and road verges (Figure 5). The soil was analyzed by taking the sample in six (6) location and determine the texture by "feel method" and $\mathrm{PH}$ in the laboratory with distilled water using $\mathrm{PH}$ meter at ASTC, Kassa Barkin Ladi, LG.A. of Plateau State(See Table 1). No form of vegetation whatsoever was found, due to the use of hard landscape elements in the surrounding exterior structures and regular trampling by pedestrians. The absence of vegetation on the site makes the site prone to extreme temperatures and weather conditions there is no form of windbreak and thermal regeneration (Figure 6).

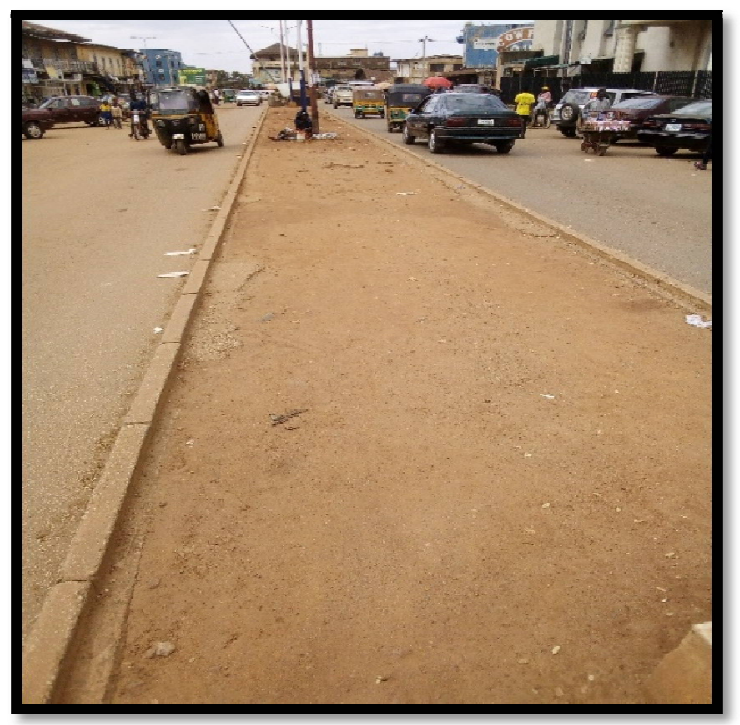

Figure 5: Soil type (sandy) on Road Verges Source: Researchers' Field Survey, 2019

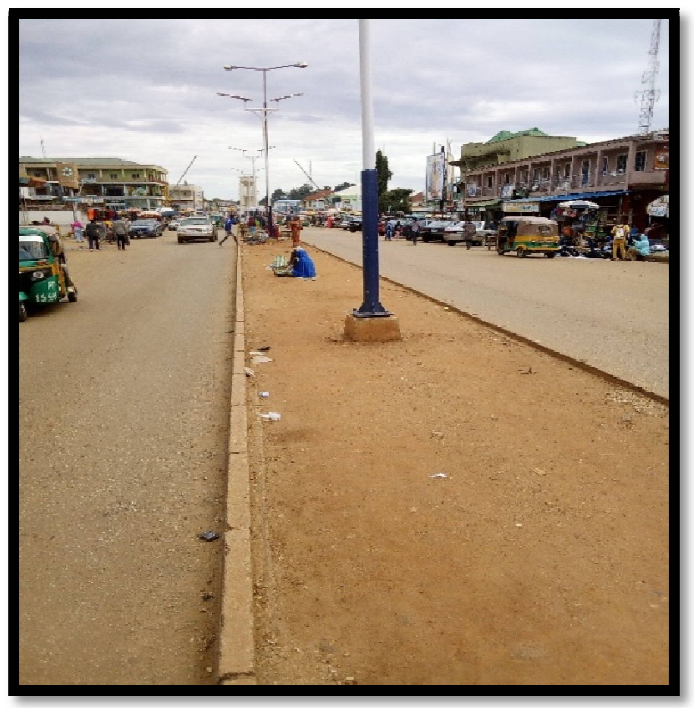

Figure 6: Absence of Softscape Elements on Road Verge

.Source: Researchers' Field Survey, 2019

\begin{tabular}{|c|c|c|c|c|}
\hline Sampling Sport & $\begin{array}{c}\text { Stickiness } \\
\text { ( Yes Or No) }\end{array}$ & Soil Type & Soil PH & Soil Temperature ( 0.C) \\
\hline Sport A & Yes & Sandy clay & 7.00 & 25.8 \\
\hline Sport B & Yes & Sandy clay & 6.51 & 26.01 \\
\hline Sport C & Non-sticky & Loamy sand & 5.98 & 25.05 \\
\hline Sport D & Yes & Clay loam & 5.15 & 26.1 \\
\hline Sport E & Non-sticky & Loamy sand & 6.36 & 26.0 \\
\hline Sport F & yes & Sandy clay & 6.0 & 26.1 \\
\hline
\end{tabular}

Table 1: Showing Soil Result by Feel Method

Source: Researchers' Field Work, 2019 


\subsubsection{Climatic Data}

The climatic values are noticeably disparate in the following areas:

\subsection{Sunlight}

The absence of trees and cover vegetation on the site makes the impact of solar radiation severe. The hottest month of the year, April, also has about the most direct sun to earth contact as the cloud cover is just gathering for the year. The trees and shrubs would have absorbed heat, cast shadows and consequently provide shades for human comfort, the reverse obtains. Surface albedo is high as a result of bare surfaces. Heat reflection and radiation from large paving such as roads and car parks are very noticeable (Audubon, 2008).

\subsection{Temperature}

The built-up neighbourhood profile of the site brings about the formation of a heat island over the central area $\left(27^{\circ} \mathrm{C}-32^{\circ} \mathrm{C}\right)$, thus increases the air temperature (Audubon, 2008).

\subsection{Wind}

Tree buffers would have only a horizontal reduction in velocity and sieving, which should be employed to give the site a favourable air circulation quality and atmosphere. Refuse waste collection points should be located adjacent to the predominant wind direction to maximize the sweeping of malodorous air and minimize scattering of disposed refuse by the wind (Audubon, 2008).

\subsection{Geology}

The general geology of Jos is JURASSIC, that is younger granite and the project site is classified under biotitegranite, group 2 (medium-grained), specifically m6 N'gell biotite granite (Audubon, 2008).

\section{Discussion}

A reconnaissance survey around the major streets of the City Centre reveals no functional and interesting use of plants in shaping, beautifying and achieving environmental management. Improper waste management culture as well as defective sanitary system allows for the gradual accumulation of municipal waste on the streets. Figure 7 shows the Torch of Unity roundabout (an iconic edifice) with no greenery on its apron while Figure 8 shows how solid waste has been accumulated on the road verges of major streets, hence no form of softs cape elements

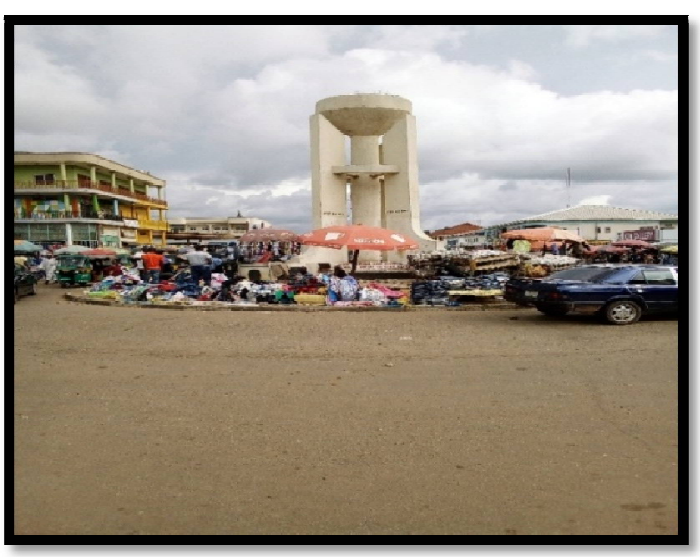

Figure 7: Absence of Greenery on Apron of Roundabout, The Roundabout Now

Serves As a Platform for the Sale of Second Hand Clothes Source: Researchers' Field Survey, 2019

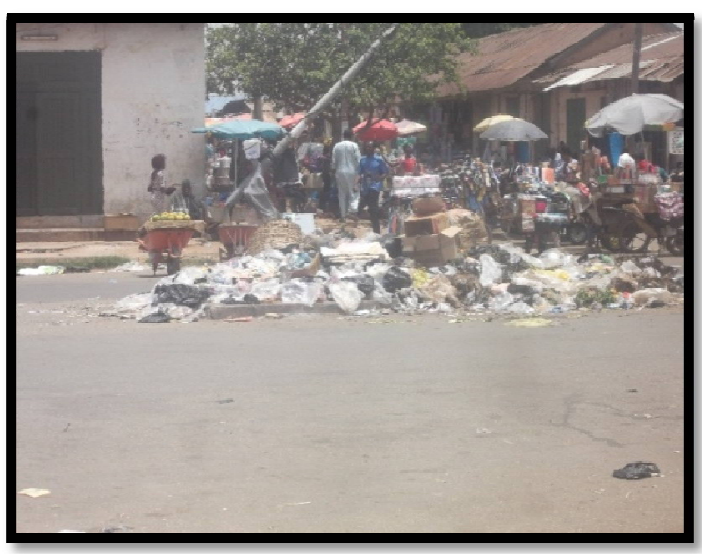

Figure 8: Accumulation of Solid Wastes on Splitter Island at Ahmadu Bello Way 
Photographic images of Figure 9 a $\&$ b reveals how the surrounding landscape of the City Centre has been distorted due to informal trading activities. No visual aesthetics and impact of solar radiation from paved surfaces and the vehicular roads is high due to absence of plant materials.

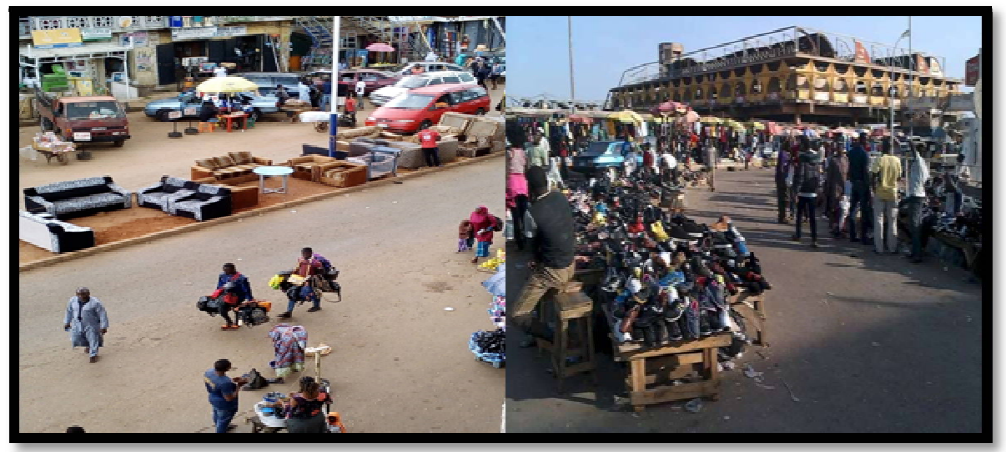

Figure 9: Open Market Goods Display on Surrounding Landscape and Absence of Softscape Element

Source: Researchers' Field Survey, 2019

Photographic images taken of Figure 10 below, reveals how about $85 \%$ of the surroundings of the facilities are covered with hard surface materials of asphalt and concrete resulting into heat islands around the exterior of the buildings. This can lead to increase of thermal discomfort.

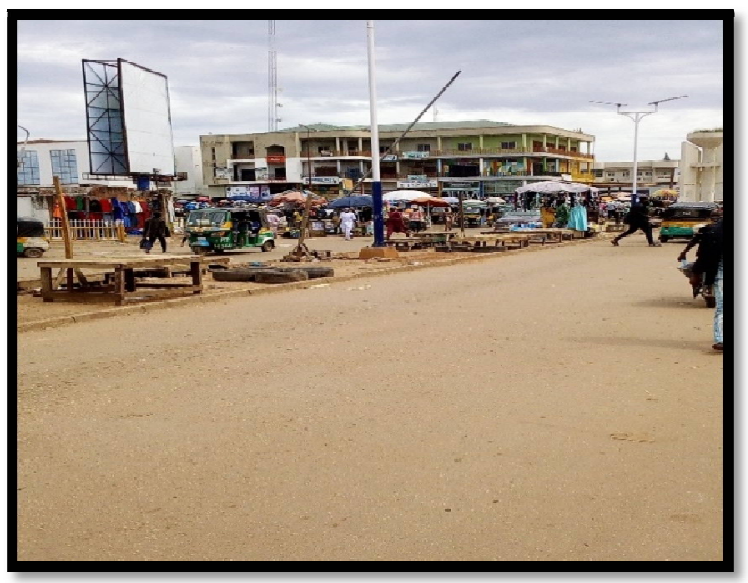

Figure 10: A Perspective View of a Major Road Were Absence of Softscape Element to

Reduce the Impact of Heat Islands around Buildings

Source: Researchers' Field Survey, 2019

The scene of Figure 11portrays the importance of trees and shrubs in providing shade to traders within the environment while Figure 12 reveals poor environmental management of drainage channels in the City Centre.

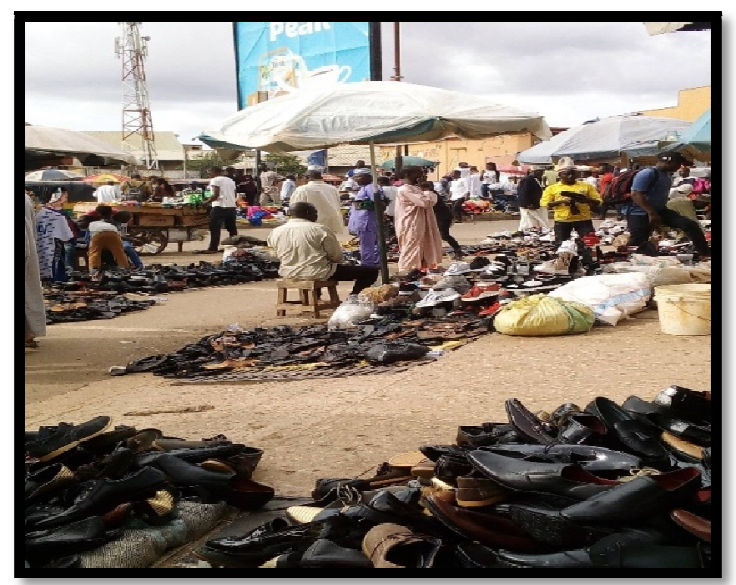

Figure 11: Traders Using Large Umbrellas as Shading Device from Harsh Elements of Weather and Climate 
Source: Researchers' Field Survey, 2019

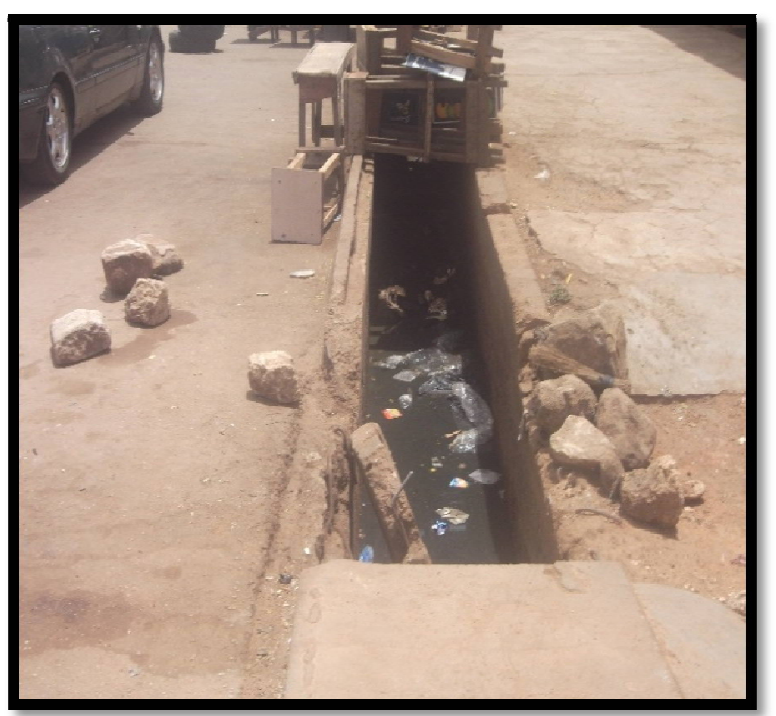

Figure 12: Broken Drainage with Stagnant Dirt Water Source: Researchers' Field Survey, 2019

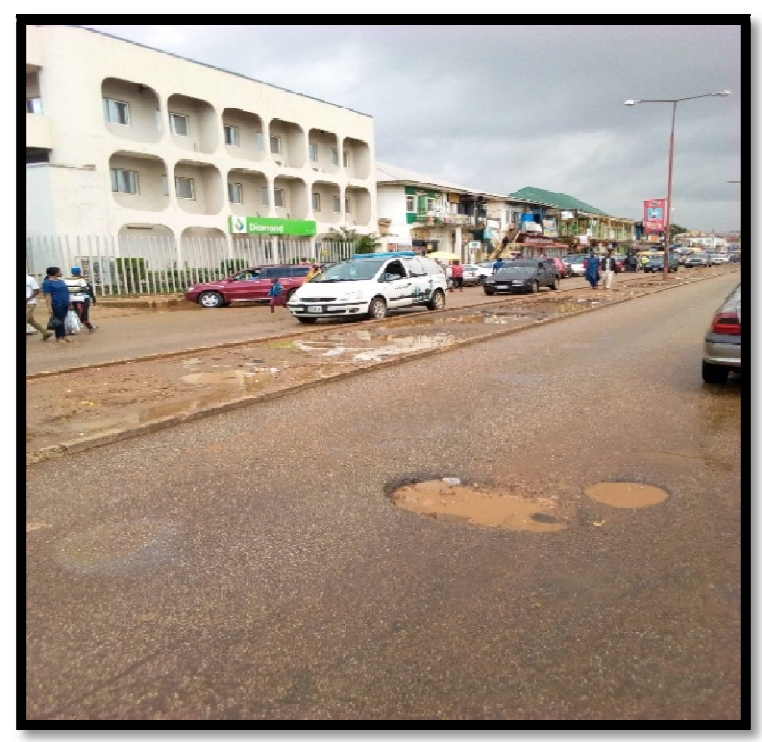

Figure 13: Absence of Landscaping Buffer on Splitter Island of the Road

Source: Researchers' Field Survey, 2019

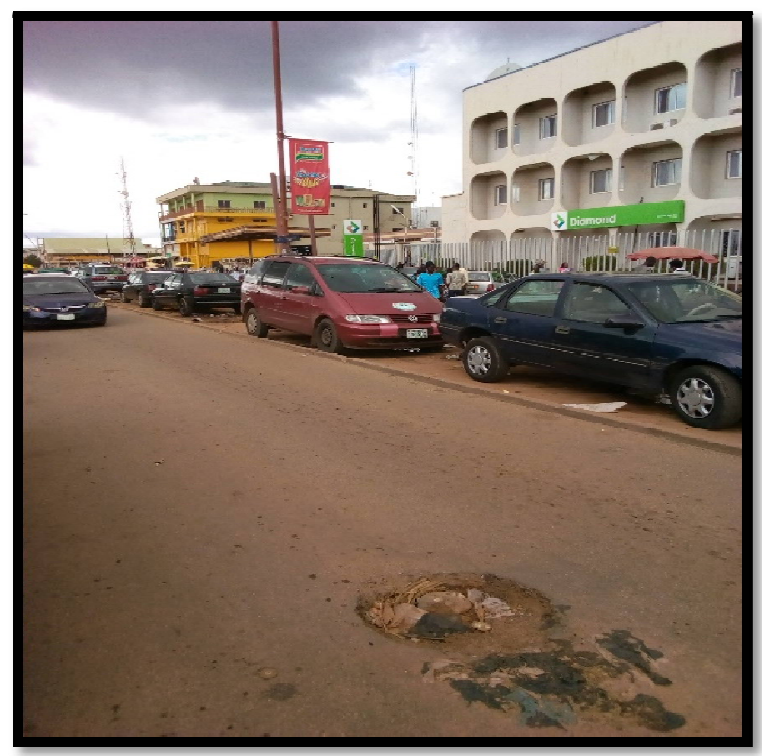

Figure 14: Cars Parked On Splitter Island of the Road 
Figure 13 reveals the absence of landscaping buffers on Splitter Island to reduce urban climate while Figure 14 reveals how the splitter island of the road has been turned to parking areas by motorist due to lack of shade trees. This causes traffic congestion too.

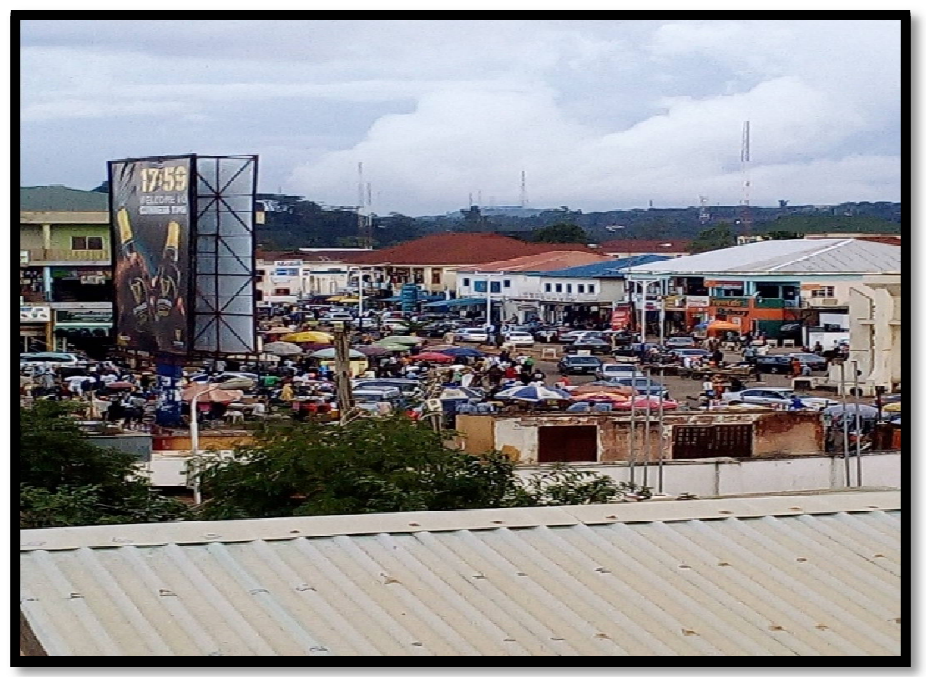

Figure 15: Aerial View of the CBD, Jos Revealing the Absence of Softscape Elements

Source: Researchers' Field Survey, 2019

Figure 15 above depicts the scene of the CBD, Jos with absence of softscape elements to reduce the impact of noise generated by traffic, act as agents that could retain and absorb rainwater, act as flood control and beneficial in reducing air pollution from vehicles, manufacturing, heating installations and natural dust.

\section{Planting Scheme}

Planting scheme is the art of installation and spacing of ornamental plants around the centre, this is meant to provide an aesthetical appeal and enhance circulation within the environment (See Table 2). The planting scheme consists of the following broad groups:

- Foundation planting

- Border planting

- Avenue planting

- Specimen planting

At this stage, plants are introduced to their appropriate locations based on the planting scheme. Watering is done afterwards. It should be ensured that watering is carried out daily when there is no rain.

\subsection{Maintenance Routine of Ornamental Plants}

Landscape maintenance is the basic upkeep of an already installed landscape, to keep a landscape functional, clean, safe and attractive. The need for maintenance cannot be over emphasized. Lack of proper maintenance of a facility or building leads to rapid dilapidation of the facility or building. Maintenance ought to be the responsibility of both the owner and users of the facility. It is an all year round activity. Maintenance activities range from mowing, pruning, watering, weeding, pest control and herbicide application, fertilization application, over seeding, spiking.

Some other maintenance activities that would be carried out would be:

- The plant materials planted on the road verges would be surrounded by a short fence of wire netting to both discourage car parking on the road verges, and a the same time prevent pedestrians crossing the road from damaging or harming the plants.

- Litter bins would be monitored to be disposed of as soon as frequently as is required.

- The plants also at the focal point would be regularly watered during the dry season and would also be protected with the short wire net fence.

- The bus stop shed, as well as the multi-storey car park would be regularly cleaned up to provide a conducive atmosphere for users.

- Dumping of refuse in the drainages would be avoided by the provision of bins and incinerators. This would further prevent the flooding that is usually experienced on the site. 


\begin{tabular}{|c|c|c|c|c|c|c|}
\hline S/ No & $\begin{array}{c}\text { Common } \\
\text { Name }\end{array}$ & Botanical Name & Plant Type & $\begin{array}{l}\text { Max.Height } \\
\text { (M) }\end{array}$ & $\begin{array}{c}\text { Canopy } \\
\text { Spread (M) }\end{array}$ & Uses \\
\hline $\begin{array}{l}1 . \\
2 . \\
3 . \\
4 . \\
5 . \\
6 . \\
7 . \\
\\
8 . \\
9 . \\
10 . \\
11 . \\
\\
12 . \\
13 . \\
14 . \\
15 . \\
16 . \\
17 . \\
18 . \\
19 . \\
20 . \\
21 . \\
22 . \\
23 . \\
24 . \\
25 . \\
26 . \\
27 . \\
28 . \\
29 . \\
30 .\end{array}$ & $\begin{array}{c}\text { Sandbox } \\
\text { Flamboyant } \\
\text { Tree } \\
\text { Siamea } \\
\text { Pine } \\
\text { Jacaranda } \\
\text { Flea Tree } \\
\text { Pride of } \\
\text { Barbados } \\
\text { Teak } \\
\text { Pongame oil } \\
\text { Tree } \\
\text { Lemon-scented } \\
\text { Tree } \\
\text { Masqurade } \\
\text { Tree } \\
\text { Royal Palm } \\
\text { Fishtail Palm } \\
\text { Croton } \\
\\
\text { Euonymus } \\
\text { Yellow Bush } \\
\text { Ixora } \\
\text { Hibiscus } \\
\text { Begonia } \\
\text { Roses } \\
\text { Bougainvillea } \\
\text { Croton } \\
\text { Queen of } \\
\text { theNight } \\
\text { Begonia } \\
\text { Caladium } \\
\text { Dumb cane } \\
\text { Calathea } \\
\text { Zoysia grass } \\
\text { Bahia grass } \\
\text { Bermuda orass }\end{array}$ & $\begin{array}{c}\text { Hura crepitans } \\
\text { Delonix regia } \\
\text { Senna siamea } \\
\text { Pinus caribae } \\
\text { Jacaranda filicifolia } \\
\text { Albizia lebbeck } \\
\text { Caesalpinia pulcherrima } \\
\text { Tectona grandis } \\
\text { Millettia pinnata } \\
\text { Eucalyptus citradora } \\
\text { Polyalthia longifolia } \\
\text { Roystonea oleracea } \\
\text { Caryota mitis } \\
\text { Codiaecum variegatum } \\
\\
\text { Euonymus spp } \\
\text { Duranta rupen } \\
\text { Ixora coccinea } \\
\text { Hibiscus spp } \\
\text { Begonia obliqua } \\
\text { Rosa sinensis } \\
\text { Bougainvillea glabra } \\
\text { Codiaeum variegatum } \\
\text { Cestrum nocturum } \\
\text { Begonia scharffi } \\
\text { Caladium bicolor } \\
\text { Dieffenbachia seguine } \\
\\
\text { Calathea ornatha } \\
\text { Zoysia tenuifolia } \\
\text { Paspalum notatum } \\
\text { Cynadon dactylon }\end{array}$ & $\begin{array}{c}\text { Palm } \\
\text { Palm } \\
\text { Shrub } \\
\text { Shrub } \\
\text { Shrub } \\
\text { Shrub } \\
\text { Shrubs } \\
\text { Shrub } \\
\text { Shrub } \\
\text { Shrub } \\
\text { Shrub } \\
\text { Potted plant } \\
\\
\text { Potted plant } \\
\text { Potted plant }\end{array}$ & $\begin{array}{c}12 \\
1.5 \\
1.2 \\
1.2 \\
1.2 \\
2.0 \\
0.5 \\
0.2 \\
1.5 \\
5 \\
1.8 \\
3 \\
0.5 \\
0.5 \\
0.5\end{array}$ & $\begin{array}{c}1.2 \\
1.2 \\
2.5 \\
1 \\
0.5 \\
1.2 \\
1.5 \\
1.2 \\
6 \\
0.3 \\
0.3 \\
0.5\end{array}$ & $\begin{array}{c}\text { Shade } \\
\text { Shade/ } \\
\text { Aesthetics } \\
\text { Shade } \\
\text { Shade/ Wind } \\
\text { Break } \\
\text { Shade } \\
\text { Shade } \\
\text { Shelterbelt } \\
\text { Shelterbelt } \\
\text { Shelter belt } \\
\text { Avenue } \\
\text { plant } \\
\text { Avenue } \\
\text { plant } \\
\text { Avenue } \\
\text { plant } \\
\text { Avenue } \\
\text { plant } \\
\text { Hedges } \\
\\
\text { Hedges } \\
\text { Hedges } \\
\text { Hedges } \\
\text { Hedges } \\
\text { Hedges } \\
\text { Hedges } \\
\text { Hedges } \\
\text { Hedges } \\
\text { Scent plant } \\
\text { Corner plant } \\
\text { Corner plant } \\
\text { Corner plant } \\
\\
\text { Corner plant } \\
\text { Lawn } \\
\text { Lawn } \\
\text { Lawn }\end{array}$ \\
\hline
\end{tabular}

Table 2: Planting Scheme and Specifications

Source: Researchers' Construct 2019

\section{Conclusion}

The main aim of this research work is to inform about the specific features, benefits and value of using plant in creating an appropriate human comfort in city centre.The study noted the benefits which are associated with the proper planning and use of landscape elements as stated by(Adams, et al., 2002; Siyanbola, 2011; Ayeni,2012;Okoronkwo, 2017) in development of the city. Plant materials of different kinds should be adopted in landscaping of the city centersin order to improve the aesthetic value. Trees of different species should be introduced at car parks, strategic and organized open spaces to control global warming by maintaining the amount of carbon (IV) oxide in the atmosphere and also serve as wind breakers.

Furthermore, other elements of landscape such as statue, fountains, and flower pots can be used to improve the landscape outlook of the city centre. A lot is expected from us to collectively work together as a team so as to change, preserve and maintain our environments from natural and man-made disasters.

\section{Recommendation}

This research recommends that adequate space planning and the use of softscape elements should be put to use in the development of city centres. Also professionals in landscape planning and other related disciplines (Horticulturists, Nursery workers, landscape planners, etc.) should be employed in the various ministries and organizations related with the management of city centers to handle issues of landscape design, planning and adherence to the proposed maintenance schedule. 
There is need for adequate funding of landscape projects as well as sensitization to residents on the importance an aesthetic environment as well as compel residents to show more concern and respect for the environment. It is further recommended that placing of street sign posts should be done to enlighten and direct people within the city centre.

\section{References}

i. Acquaah, G. (2009). Horticulture - principles and practices (4th ed.). New Jersey: Pearson Education Inc.

ii. Adams, B.A., Osikabor, B \& Akoun, J. (2002).The Place of plants in landscaping as a strategy for effective environment management and beautification of Urban Centres. In: Umeh, V. C. and Fagbayide, J .A. Proceedings of the Annual Conference of Horticultural Society of Nigeria (HORTSON) 14th $-17^{\text {th }}$ May, 2002. pp 202-204.

iii. Agbonome, P.C. \& Abazuonu, L. C. (2014).The Value of architectural Landscaping on Buildings in Nigerian Cities.Tropical Built Environment Journal (TBEJ), 1(4), 441-451.

iv. Ale, A. \& Ayeni, D. A. (2019).Achieving Thermal Comfort Using Landscape Elements in Resorts.In Oluigbo, S.N. and Sagada, M.L. Procs. of Association of Architectural Educators in Nigeria (AARCHES) National Conference: Extending the Frontiers of Architecture.18-20 June, 2019, Zaria, Nigeria. pp 207-222

v. Archives of National Centre for Remote Sensing, Jos 2007.

vi. Ayeni, D. A.(2012). Enhancing and Developing Sustainable Tourism through Landscaping in Nigeria. Unpublished Ph.D. Thesis, De Montfort University, Leicester, United Kingdom.

vii. Bello,A.V. (2015). The effect of landscaping on rental values of residential property in Ijapo housing estate Akure, NigeriaAfrican Journal of Geo-Science Research, 4(1), 1-6

viii. Central Public Works Department (2013). A Handbook of Landscape - A Guide. New Delhi.

ix. Fadamiro, J. A, Ajenifujah, A. O., \&Ayeni, D.A. (2008) Landscape asa Veritable Tool to Environmental Sustainability: Introducing Green Practices.2nd International Conference on Built Environment in Developing Countries (ICBEDC 2008) pp.1744-1755

x. Ibimilua, A.F. (2014). Key Issues on Landscape Planning in the Context of Environmental Sustainability. European Scientific Journal, 10(2), 143-156.

xi. Mbah, N.B. (2001). Horticultural initiatives to current environmental concerns. In: Proceedings of the 19th Annual Conference of Horticultural Society of Nigeria (HORTSON) held at University of Nigeria Nnsuka. 28th May -1st June, 2001.pp 1-5.

xii. NNA/ISSA, (1991).The importance of large tree maintenance in mitigation global climate change.Amhest, U.S.A., National Arborist Association.

xiii. Oko, J. (2016).The Architectural Plausibility of an Urban Parking FacilityProject: A Jos City Centre Scenario.Civil and Environmental Research.8(7), 7-17.

xiv. Okoronkwo, N.C. (2017). Proposed landscape re-design for Jos city centre. Unpublished HND Thesis, Federal College of Forestry, Jos.

xv. Omokhua, G., Idumah, F., \& Koyejo,OA.(2002).Environmental importance of horticulture in Nigeria.In: Umeh, V. C. and Fagbayide, J .A. Proceedings of the Annual Conference of Horticultural Society of Nigeria (HORTSON) $14^{\text {th }}-17^{\text {th }}$ May, 2002.pp 200-202.

xvi. Siyanbola, A.B. (2011).The impact of soft landscaping on the microclimate of a typical Bungalow in akure. A term paper submitted to Department of Architecture School of Post Graduate Studies. Federal University of Technology, Akure.

xvii. University of Jos (Rev.ed.). (2017). Guidelines for preparation and submission of theses and dissertations and issues in quality research enhancement. Jos: School of Postgraduate Studies. 